\title{
SELECTION OF DROUGHT TOLERANT RICE VARIETIES FOR THE WESTERN MID HILLS OF NEPAL
}

\author{
B. B. Adhikari ${ }^{1}$, B. Mehera ${ }^{2}$ and S.M. Haefele ${ }^{3}$ \\ ${ }^{1}$ Institute of Agriculture and Animal Sciences, Tribhuvan University, Nepal \\ ${ }^{2}$ Sam Higginbottom Institute of Agriculture, Technology and Sciences (SHIATS), India \\ ${ }^{3}$ The University of Adelaide, Adelaide, Australia
}

\begin{abstract}
Rice (Oryza sativa L) is the most important staple food crop in Nepal, but current yields are low and total production varies, mostly due to drought. To evaluate high yielding and drought tolerant rice genotypes in typical rainfed lowland conditions, a participatory varietal selection trials was conducted with farmers in farmer's field at Sundarbazar, Lamjung, Nepal during the wet season 2009 and 2010.Trials were laid out in a Randomized Complete Block Design with six replications. Results obtained from two years' experiment indicated that the genotypes IR74371-54-1 and IR74371-70-1 matured at the same duration as the local check Radha-4 (120-123 days growth duration). Both genotypes had a high average chlorophyll content (SPAD reading of 15.9-16.1), were medium tall (110-112 cm), non-lodging, had a high number of filled grains and little sterility, and a high grain yield (mean yield 5.0 and $4.8 \mathrm{tha}^{-1}$, respectively). They also had the highest root length $(22.4-26.2 \mathrm{~cm})$ and root weight $\left(9.5-10 \mathrm{~g} \mathrm{hill}^{-1}\right)$ which could tolerate more drought than the other genotypes tested. The maximum cost/benefit ratio was found in IR-7437154-1 (1:1.72) followed by IR-74371-70-1 (1:1.66) and IR-74371-46-1-1 (1:1.65). All three lines were highly preferred by farmers in preference rankings during field visits and were released in Nepal in 2011 as Sookhadhan-2, Sookhadhan-3 and Sookhadhan-1 varieties, respectively. They fit easily into the existing cropping system in rainfed lowlands, are economically viable and safe to cultivate for the farmers in the mid hills of Nepal.
\end{abstract}

Key words: Drought, participatory varietal selection, rainfed rice, yield

\section{INTRODUCTION}

Rice (Oryza sativa $\mathrm{L}$ ) is the most important staple food crop in reference to area of cultivation as well as amount of production in Nepal, followed by maize and wheat. It is annually grown on 1.50 million hectares, producing about 4.5 million tons, indicating an average yield of 2.98 tons ha $^{-1}(M O A D, 2012 / 013)$. Rice is grown on half of the total cropped area and contributes more than half of the total food grain production in the country. Almost three quarters $(71.6 \%)$ of the total rice area in Nepal is located in the Terai,whereas only about 24.8 and $3.6 \%$ of the rice area are located in the mid hill and mountain regions, respectively. Rice contributes nearly $20 \%$ to the Agricultural Gross Domestic Product (AGDP) and provides more than $50 \%$ of the total calories required by the Nepalese people (MoAC, 2009).

In the past, production increases in Nepal have been achieved mainly through an expansion of the crop area. However, suitable land for production is becoming scarce and further expansion is often not further possible. The option to increase local food production therefore may be intensification of farming and/or reduction of losses. Production increases are probably easiest to achieve in the large lowland systems of the Terai, but production growth in the hills and mountain areas is equally 
important for improving food security in these regions where poor transportation infrastructure precludes efficient food transfer from the Terai.

In the Mid-hills, most of the rice is cultivated in terraced, bunded fields without irrigation. Consequently, water recipient of rice is mostly irregular as they either experiencetoo little or too much water, resulting in the relatively low grain yield average of $2.34 \mathrm{t} \mathrm{ha}^{-1}$, which is below the national average of about $2.71 \mathrm{tha}^{-1}$ (Pandey et al., 2007). Apart from this predominant abiotic stresses, low yields are also attributed to sub-optimal crop management practices, and in particular to suboptimal nutrient management (Sherchan and Karki, 2006). To increase productivity of rice in Nepal, the agricultural research institutions have provided several need-based, output-oriented management recommendations but they are rarely practiced in farmers' fields (Joshy and Rajbhandadri, 2001). However, detailed on-farm studies evaluating the yield gap in rainfed lowland rice and determining the varieties contributing to the yield gap in the mid-hills of Nepal are rare. A recent study by Haefele et al. (2014) indicated that grain yields in the Mid-hills vary considerably between different landscape positions and distances from the house, mainly depending on the nutrient supply and available water resources. Highest grain yields were observed in the field which were near the house whereas lowest yield were seen in the field far from the house and on upper fields were water resources and nutrient supplies are limited. This might be due to proper care of the field near the house. The yield gap between farmers' nutrient management practice and a medium fertilizer rate $\left(60-30-20 \mathrm{~N}-\mathrm{P}_{2} \mathrm{O}_{5}-\mathrm{K}_{2} \mathrm{O}\right.$ $\mathrm{kg} \mathrm{ha}^{-1}$ ) was $0.5 \mathrm{tha}^{-1}$ across all fields tested.

A large portion of the total rice area in Nepal is rainfed (about $65 \%$ ), and high yearly and seasonal fluctuations of rainfall cause concurrent fluctuations of total rice production. Since, rice is quite susceptible to water stress, and drought can cause severe damage at any stage of rice growth and development, this rainfed situation may lead to a partial or complete yield loss. However in present days, breeders have developed some drought-tolerant rice cultivars for such regions as a consequence, farmers in such environments may either use low yielding traditional-type varieties with some adaptation to drought, or high yielding modern-type varieties with very little tolerance of drought stress.

To address this issue, participatory varietal selection trials were conducted in the farmers' field at Sundarbazar, Lamjung, Nepal during the wet season 2009 and 2010, to evaluate high yielding and drought tolerant rice genotypes in typical rainfed lowland conditions. Specific objectives were to (i) select high yielding and drought tolerant rice varieties that fulfill farmers' needs in rainfed environments of the Mid-hills of Nepal, (ii) to determine the possible yield advantage in comparison with currently used varieties such germplasm could provide, and (iii) to determine varietal characteristics contributing to their drought tolerance.

\section{MATERIALS AND METHODS}

The experiment was conducted in Sundarbazar Village Development Committee (VDC) of Lamjung district of Nepal during wet seasons 2009 and 2010. The experimental sites were located the southern part of Lamjung (latitude from $28^{\circ} 7^{\prime}$ to $28^{\circ} 10^{\prime}$ North, and longitude from $84^{\circ} 24^{\prime}$ to $84^{\circ}$ $28^{\prime}$ 'East), at an altitude between 600 and $800 \mathrm{~m}$ asl.

The study area represents a unique set of farming system that resembles many similar areas in the Mid-hills of Nepal, where drought is a major constraint and poverty alleviation has remained a central issue. In general, the site receives ample rainfall during the rainy season from June to 
September, and usually June and July receive the highest amount of rainfall. The average annual rainfall is around $2000 \mathrm{~mm}$.

The experiment was conducted using a Randomized Complete Block Design (RCBD) in six farmer's fields. Each farmer represented one replication. A composite soil sample from the complete trial areas and a depth of $0-0.1 \mathrm{~m}$ was taken in 2009 before the season started. Soil analysis was conducted at the Analytical Service Laboratory (ASL) of the International Rice Research Institute (IRRI), Philippines.

A total of seven promising lines from the drought screening network of IRRI were evaluated together with a local check variety (Radha-4). The sub-plot size was 3m x 3m, where two seedlings per hill were planted with a hill spacing of $0.2 \mathrm{~m} \times 0.2 \mathrm{~m}$. Basally applied were the equivalent of 6 tons ha- ${ }^{-1} \mathrm{FYM}$ and 30:30:20 kg N:P $\mathrm{O}_{5}: \mathrm{K}_{2} \mathrm{O}$ ha $^{-1}$ as urea, DAP and MOP. In addition, $30 \mathrm{~kg} \mathrm{~N}$ was topdressed at 20 and 40 days after transplanting (DAT). All field management activities from seeding to harvesting were done by the participant farmers under researcher's guidance. During the grain filling stage of the crop, farmers were involved in preference ranking by casting the votes based on varietal traits. The preference index was calculated for each genotype by using the following formula.

$$
\text { Preference index }=\frac{\text { No. of positive votes }- \text { No. of negative votes }}{\text { Total votes cast }}
$$

Harvesting was done from the net plot $\left(2.2 \mathrm{~m} \times 3 \mathrm{~m}=6.6 \mathrm{~m}^{2}\right)$ and the grain yield, biological yield and harvest index were computed using the following formulae (MC is the moisture content in percentage of the grains):

1) Gain yield $\left(\mathrm{kg} \mathrm{ha}^{-1}\right)$ at $14 \%$ moisture $=\frac{(100-\mathrm{MC}) \times \text { Plotyielding } \mathrm{kg}}{(100-14) \times \text { Netplot area } \mathrm{m} 2} \chi 10000(\mathrm{~m} 2)$

2) Biological yield $\left(\mathrm{kg} \mathrm{ha}^{-1}\right)=$ Grain yield $(\mathrm{kg})+$ Straw yield $(\mathrm{kg})$

3) Harvest index $(\%)=\frac{\text { Grain yield }(\mathrm{kg})}{\text { Grain yield }(\mathrm{kg})+\text { Straw yield }(\mathrm{kg})} \chi 100$

The chlorophyll content of leaves was measured using a Minolta chlorophyll meter (model SPAD 502) at seven day intervals from 15 days after transplanting to just before harvesting (total 12 readings with 3 replications in each reading). The economic analysis was conducted to determine the profitability of treatments used in the experiment. The cost of production and profit of each treatment was calculated based on the local market price of different agro-inputs used and the farm gate paddy and straw price in each year. The benefit/cost ratio (B/C ratio) was calculated according to: $\mathrm{B} / \mathrm{C}$ ratio $=$ Gross return / Cost of cultivation, based on Bhandari (1993).

\section{Soil properties}

\section{RESULTS AND DISCUSSION}

The initial pre-planting soil properties of the area under study is shown in Table 1 . In the field, the soil texture was sandy loam with a slightly acidic $\mathrm{pH}(6.4 \mathrm{pH})$, relatively high organic carbon contents (2.52\%), adequate total N (25\%), less available P contents $(4 \mathrm{mg} / \mathrm{kg})$. The cation exchange capacity was $6.5 \mathrm{cmol} \mathrm{kg}^{-1}$ soil, and the base saturation was $86 \%$, corresponding to the $\mathrm{pH}$. Thus, field had similar soil fertility characteristics even if some differences between terraces. 
Table 1. Physio-chemical properties of soil in the experiment in 2009.

\begin{tabular}{lllc}
\hline & Soil characteristic & Unit & Value \\
\hline 1 & Soil pH (1:1) & - & 6.40 \\
2 & Organic carbon & $\%$ & 2.52 \\
3 & Total nitrogen & $\%$ & 0.25 \\
4 & Available phosphorus & $\mathrm{mgkg}^{-1}$ & 4.0 \\
5 & Exchangeable potassium & $\mathrm{cmol}^{+} \mathrm{kg}^{-1}$ & 0.44 \\
6 & Exchangeable sodium & $\mathrm{cmol}^{+} \mathrm{kg}^{-1}$ & 0.04 \\
6 & Exchangeable calcium & $\mathrm{cmol}^{+} \mathrm{kg}^{-1}$ & 4.44 \\
7 & Exchangeable magnesium & $\mathrm{cmol}^{+} \mathrm{kg}^{-1}$ & 0.72 \\
8 & Cation exchange capacity & $\mathrm{cmol}^{+} \mathrm{kg}^{-1}$ & 6.54 \\
9 & Sum of bases & $\mathrm{cmol}^{+} \mathrm{kg}^{-1}$ & 5.64 \\
10 & Base saturation & $\%$ & 86 \\
11 & Available zinc & $\mathrm{mgkg}^{-1}$ & 3.1 \\
12 & Clay & $\%$ & 11 \\
13 & Sand & $\%$ & 66 \\
14 & Silt & $\%$ & 23 \\
\hline
\end{tabular}

\section{Phenology and growth characters}

The number of days to maturity, plant height, flag leaf area and chlorophyll content of the tested genotypes are presented in Table 2. Genotypes like IR-78908-193, IR-83614-281-B and IR-83614673-B matured significantly earlier (116-117 days) whereas the best performing genotypes IR-7437154-1-1, IR-74371-46-1 and IR-74371-70-1 matured at the same time (120-123 days) as Radha-4, the local check variety. The duration was very similar in both seasons and all tested genotypes were of a medium duration type, easily fitting into the existing cropping system and with a limited drought risk at the end of the normal cropping season. In drought-prone rainfed environments, short duration may reduce the risk of drought damage at the end of the season but limits the accumulation of sufficient indigenous nutrients necessary in an environment where little external nutrients are applied.

Table 2. Duration, plant height, flag leaf area and chlorophyll content of the tested genotypes.

\begin{tabular}{|c|c|c|c|c|c|c|c|c|}
\hline \multirow[t]{2}{*}{ Genotypes } & \multicolumn{2}{|c|}{$\begin{array}{c}\text { Duration (days } \\
\text { from seeding to } \\
\text { maturity) } \dagger\end{array}$} & \multicolumn{2}{|c|}{$\begin{array}{l}\text { Plant height } \\
\qquad(\mathrm{cm}) \dagger\end{array}$} & \multicolumn{2}{|c|}{$\begin{array}{l}\text { Flag leaf area } \\
\qquad\left(\mathrm{cm}^{2}\right) \dagger\end{array}$} & \multicolumn{2}{|c|}{$\begin{array}{c}\text { Chlorophyll } \\
\text { content } \\
\text { (SPAD value) } \dagger\end{array}$} \\
\hline & 2009 & 2010 & 2009 & 2010 & 2009 & 2010 & 2009 & 2010 \\
\hline 1. IR-74371-70-1-1 & $120.8^{\mathrm{b}}$ & $121.2^{\mathrm{a}}$ & $104^{\mathrm{d}}$ & $116^{\mathrm{cd}}$ & $65.7^{\mathrm{bc}}$ & $72.8^{\mathrm{b}}$ & $15.0^{\mathrm{ab}}$ & $15.6^{\mathrm{ab}}$ \\
\hline 2. IR-55419-04 & $121.7^{\mathrm{ab}}$ & $121.3^{\mathrm{a}}$ & $101^{\mathrm{d}}$ & $118.6^{\mathrm{cd}}$ & $62.7^{\text {cde }}$ & $73.6^{\mathrm{b}}$ & $14.0^{\mathrm{b}}$ & $14.8^{\mathrm{bc}}$ \\
\hline 3. IR-74371-46-1-1 & $122.7^{\mathrm{a}}$ & $121.7^{\mathrm{a}}$ & $104^{\mathrm{d}}$ & $119.4^{\mathrm{c}}$ & $66.9^{\mathrm{ab}}$ & $78.1^{\mathrm{a}}$ & $15.0^{\mathrm{ab}}$ & $15.8^{\mathrm{a}}$ \\
\hline 4. IR-74371-54-1-1 & $121.7^{\mathrm{a}}$ & $122.0^{\mathrm{a}}$ & $103^{\mathrm{cd}}$ & $118.3^{\mathrm{cd}}$ & $69.9^{\mathrm{a}}$ & $77.6^{\mathrm{a}}$ & $16.1^{\mathrm{a}}$ & $15.9^{\mathrm{a}}$ \\
\hline 5. IR-78908-193-B-3-B & $116.0^{\mathrm{c}}$ & $116.5^{\mathrm{b}}$ & $125^{\mathrm{a}}$ & $140.8^{\mathrm{a}}$ & $65.3^{\mathrm{bc}}$ & $69.8^{c}$ & $14.6^{\mathrm{ab}}$ & $14.7^{\mathrm{c}}$ \\
\hline 6. IR-83614-281-B & $116.7^{\mathrm{c}}$ & $116.7^{\mathrm{b}}$ & $116^{\mathrm{b}}$ & $131.8^{\mathrm{b}}$ & $61.7^{\mathrm{de}}$ & $66.8^{d}$ & $16.0^{\mathrm{a}}$ & $15.6^{\mathrm{ba}}$ \\
\hline 7. IR-83614-673-B & $116.7^{\mathrm{c}}$ & $116.8^{\mathrm{b}}$ & $111^{\mathrm{bc}}$ & $130.8^{\mathrm{b}}$ & $60.3^{\mathrm{e}}$ & $66.7^{\mathrm{d}}$ & $16.0^{\mathrm{a}}$ & $14.8^{\mathrm{bc}}$ \\
\hline 8. Radha-4 & $123.0^{\mathrm{a}}$ & $121.3^{\mathrm{a}}$ & $93^{\mathrm{e}}$ & $113.9^{\mathrm{d}}$ & $64.5^{\mathrm{bcd}}$ & $72.7^{\mathrm{bc}}$ & $15.0^{\mathrm{ab}}$ & $14.5^{\mathrm{c}}$ \\
\hline S.Ed $( \pm)$ & 0.65 & 0.51 & 2.95 & 2.45 & 1.64 & 1.45 & 0.78 & 0.37 \\
\hline LSD (0.05) & 1.47 & 1.04 & 6.00 & 5.29 & 3.34 & 2.93 & 1.59 & 0.75 \\
\hline CV(\%) & 0.94 & 0.74 & 4.78 & 3.42 & 4.41 & 3.47 & 8.91 & 4.24 \\
\hline
\end{tabular}

$\%$ Values in a column with the same letter(s) are not significantly different at $P=0.05$ according to Duncan's Multiple Range Test. S.Ed: standard error of mean difference, LSD: least significant difference, $C V$ : coefficient of variation; 
The average plant height indicated highly significant differences between the lines tested in both years. The varieties IR-83614-673, IR-83614-281 and IR-78908-193 were all relatively tall whereas the other varieties were medium tall. This characteristic went together with the shorter growth duration and smaller flag leaves. Across the two seasons, plant height as well as flag leaf area were higher in the second season, corresponding to the better growth conditions resulting from higher rainfall in 2010. Differences in flag leaf chlorophyll content were statistically significant in both years (Table 2). Maximum chlorophyll content in both seasons was found in IR-74371-54-1, followed by IR-83614-281-B and IR-83614-673-B. The lowest flag leaf chlorophyll content was observed in IR-55419-04, IR-78908-193-B-3-B and Radha-4. Although these growth characters are not the only ones determining germplasm performance, they are at least important contributors. Tall plants usually produce more straw and lower yields and, according to Reddy and Reddy (2002), the ideal rice plant should be of medium height. In a canopy, the flag leaf is most exposed to radiation and thus very important for photosynthesis and assimilation of the crop. Thus it can be assumed that germplasm with medium duration, of small to medium height, with a big flag leaf area and a high chlorophyll content can accumulate more dry matter than others (Adhikari, 2009). For the small set of germplasm described here, this is confirmed by the good performance of the genotype IR74371-54-1-1 (medium duration, medium height, large flag leaf area, highest chlorophyll content) as compared with for example the genotype IR-83614-673-B (short to medium duration, tall, small flag leaf area, low chlorophyll content).

\section{Yield attributes}

Statistically significant differences were found in average panicle length which ranged from 23 to $26 \mathrm{~cm}$ in both seasons. In both seasons, the three tall entries (IR78908-193, IR-83614-281, IR83614-673) were also characterized by relatively long panicles $(24.9-26.3 \mathrm{~cm})$, whereas all other lines had much shorter panicles $(22.6$ to $24.8 \mathrm{~cm})$. Among the test lines, the shortest panicles in both years were observed in IR-55419-04 (22.6 and $23.7 \mathrm{~cm})$, which was almost identical to the local check variety Radha-4 $(22.7$ and $23.0 \mathrm{~cm})$. Regarding number of productive tillers, the highest numbers were found in Radha-4 (285) and IR-83614-673-B (292). Whereas the least number of productive tillers were obseved in IR-55419-04 and IR-74371-46 (219 tillers/ $\mathrm{m}^{2}$ ). All other lines were found between this range. Although not fully consistent, the three tall lines tested (IR-78908193, IR-83614-281, IR-83614-673) tended to have more productive tillers than the other lines, but the increase in the better season 2010 seemed to be similar in both groups (plus 22-33 tillers $\mathrm{m}^{-2}$ in the group of three tall lines, plus 18-42 tillers $\mathrm{m}^{-2}$ in the other test lines). Regarding non-productive tillers, statistically significant differences were observed in the tested genotypes in both years. Radha-4 had highest number of non-productive tillers (17 tillers $\mathrm{m}^{-2}$ ) during 2009 while IR-78908193 (18 tillers $\left.\mathrm{m}^{-2}\right)$ and IR-83614-281 (16 tillers $\left.\mathrm{m}^{-2}\right)$ had highest non-productive tillers in 2010. The number of filled and unfilled grains per panicle during 2009 were not significantly different however differences were found significant in 2010 (Table 3 and 4). In 2009, filled grains per panicle ranged between 124 and 131 grains per panicle, whilst in the wetter season 2010 it ranged between 131 and 179 grains panicle ${ }^{-1}$. The three tall lines tested (IR78908-193, IR-83614-281, IR83614-673) tended to have lower numbers of filled grains panicle ${ }^{-1}$, and the increase in the better season 2010 was much less for them than for the other tested lines (plus 6-13 filled grains panicle ${ }^{-1}$ in 2010, plus 29-49 filled grains panicle ${ }^{-1}$ for the other test lines). Radha-4 behaved like the tall lines for this characteristic. This indicated that the three tall lines tested (IR78908-193, IR-83614-281, IR83614-673) were less responsive in more favorable conditions, and the most responsive line with respect to productive tiller number and filled grains panicle ${ }^{-1}$ was the line IR-74371-54 (plus 42 tillers $\mathrm{m}^{-2}$ and plus 49 filled grains panicle ${ }^{-1}$ in 2010 as compared with 2009). 
Table 3. Panicle length, productive and non-productive tillers per square meter and filled grains per panicle of the tested genotypes.

\begin{tabular}{|c|c|c|c|c|c|c|c|c|}
\hline \multirow[t]{2}{*}{ Genotypes } & \multicolumn{2}{|c|}{$\begin{array}{c}\text { Panicle } \\
\text { length }(\mathrm{cm}) \dagger\end{array}$} & \multicolumn{2}{|c|}{$\begin{array}{c}\text { Productive tillers } \\
\mathrm{m}^{-2} \dagger\end{array}$} & \multicolumn{2}{|c|}{$\begin{array}{l}\text { Non-productive } \\
\text { tillers } \mathrm{m}^{-2} \dagger\end{array}$} & \multicolumn{2}{|c|}{$\begin{array}{l}\text { Filled grains } \\
\text { panicle }^{-1} \dagger\end{array}$} \\
\hline & 2009 & 2010 & 2009 & 2010 & 2009 & 2010 & 2009 & 2010 \\
\hline 1. IR-74371-70-1-1 & $24.1^{b}$ & $24.8^{b}$ & $241.7^{\mathrm{ab}}$ & $254.2^{\text {bcd }}$ & $5.2^{\mathrm{c}}$ & $14.8^{\mathrm{ab}}$ & 130.5 & $165^{\mathrm{ab}}$ \\
\hline 2. IR-55419-04 & $22.6^{\mathrm{c}}$ & $23.7^{b c}$ & $219.2^{b}$ & $250.0^{\mathrm{cd}}$ & $9.0^{\mathrm{bc}}$ & $14.6^{\mathrm{ab}}$ & 125.5 & $149^{\mathrm{bcd}}$ \\
\hline 3. IR-74371-46-1-1 & $23.6^{\mathrm{bc}}$ & $23.3^{\mathrm{c}}$ & $219.2^{b}$ & $237.5^{\mathrm{d}}$ & $9.8^{\mathrm{bc}}$ & $13.5^{\mathrm{ab}}$ & 130.2 & $159^{\mathrm{abc}}$ \\
\hline 4. IR-74371-54-1-1 & $23.5^{\mathrm{bc}}$ & $23.8^{\mathrm{bc}}$ & $232.5^{\mathrm{ab}}$ & $275.0^{\mathrm{abc}}$ & $9.7^{\mathrm{bc}}$ & $11.3^{\mathrm{b}}$ & 130.2 & $179^{a}$ \\
\hline 5. IR-78908-193-B-3-B & $24.9^{\mathrm{ab}}$ & $26.3^{\mathrm{a}}$ & $253.3^{\mathrm{ab}}$ & $275.0^{\mathrm{abc}}$ & $9.0^{\mathrm{bc}}$ & $17.6^{\mathrm{a}}$ & 123.7 & $137^{\mathrm{cd}}$ \\
\hline 6. IR-83614-281-B & $26.2^{\mathrm{a}}$ & $26.2^{\mathrm{a}}$ & $229.2^{\mathrm{b}}$ & $258.3^{\mathrm{abcd}}$ & $8.0^{\mathrm{bc}}$ & $15.8^{\mathrm{ab}}$ & 125.2 & $131^{\mathrm{d}}$ \\
\hline 7. IR-83614-673-B & $25.6^{\mathrm{a}}$ & $26.1^{\mathrm{a}}$ & $258.3^{\mathrm{ab}}$ & $291.7^{\mathrm{a}}$ & $12.5^{\mathrm{ab}}$ & $15.3^{\mathrm{ab}}$ & 125.0 & $135^{\mathrm{d}}$ \\
\hline 8. Radha-4 & $22.7^{\mathrm{c}}$ & $23.0^{\mathrm{c}}$ & $285.0^{\mathrm{a}}$ & $288.3^{\mathrm{ab}}$ & $16.8^{\mathrm{a}}$ & $14.2^{\mathrm{ab}}$ & 129.3 & $132^{\mathrm{d}}$ \\
\hline S.Ed $( \pm)$ & 0.66 & 0.55 & 25.63 & 545.0 & 3.13 & 2.87 & 4.96 & 10.78 \\
\hline $\operatorname{LSD}(0.05)$ & 1.34 & 1.12 & 52.05 & 36.56 & 6.36 & 5.84 & 10.07 & 21.9 \\
\hline $\mathrm{CV}(\%)$ & 4.73 & 3.90 & 18.33 & 11.72 & 54.3 & 33.98 & 6.74 & 12.60 \\
\hline
\end{tabular}

$\%$ Values in a column with the same letter(s) are not significantly different at $P=0.05$ according to Duncan's Multiple Range Test. S.Ed: standard error of mean difference, LSD: least significant difference, $C V$ : coefficient of variation;

The number of unfilled grains and of spikelet sterility did not indicate a clear trend between test lines, but across lines higher values for both characteristics were observed in 2010 (Table 4). The sterility percentage in the tested genotypes and in both seasons seemed to be related to the weather conditions. In 2009, the sterility was probably caused by a long drought period during grain setting; only $21 \mathrm{~mm}$ rainfall occurred in the grain setting month of September (Adhikari, 2009). In contrast, in 2010 the sterility might have been due to heavy rainfall at the time of pollination and fertilization (257 $\mathrm{mm}$ rainfall in September, coinciding with the peak period of pollination and fertilization. Statistically significant differences for test weight were detected in both years, and the average test weight was $25.5 \mathrm{~g}$ in 2009 and $26.6 \mathrm{~g}$ in 2010 , probably caused by environmental effects. The highest test weight in both seasons was achieved in Radha-4 (26.4 g in 2009 and $28.6 \mathrm{~g}$ in 2010). All tested genotypes had a coarse grain type with medium to low market price.

Table 4. Unfilled grains per panicle, sterility percent, test weight and shattering percentage of the tested genotypes.

\begin{tabular}{|c|c|c|c|c|c|c|c|c|}
\hline \multirow[t]{2}{*}{ Genotypes } & \multicolumn{2}{|c|}{$\begin{array}{c}\text { Unfilled grains } \\
\text { panicle }^{-1} \dagger\end{array}$} & \multicolumn{2}{|c|}{$\begin{array}{l}\text { Sterility } \\
(\%)+\end{array}$} & \multicolumn{2}{|c|}{$\begin{array}{l}\text { Test weight } \\
(\mathrm{g}){ }^{\dagger}\end{array}$} & \multicolumn{2}{|c|}{$\begin{array}{c}\text { Shattering } \\
(\%) \dagger\end{array}$} \\
\hline & 2009 & 2010 & 2009 & 2010 & 2009 & 2010 & 2009 & 2010 \\
\hline 1. IR-74371-70-1-1 & 23.7 & $26.6^{\mathrm{ab}}$ & 15.6 & $16.9^{\mathrm{ab}}$ & $24.7^{b}$ & $25.2^{\mathrm{e}}$ & $8.4^{\mathrm{bc}}$ & $13^{\mathrm{c}}$ \\
\hline 2. IR-55419-04 & 25.0 & $24.0^{\mathrm{ab}}$ & 17.1 & $17.2^{\mathrm{ab}}$ & $26.1^{\mathrm{a}}$ & $27.4^{\mathrm{b}}$ & $12.3^{\mathrm{a}}$ & $18^{\mathrm{a}}$ \\
\hline 3. IR-74371-46-1-1 & 21.2 & $26.3^{\mathrm{ab}}$ & 14.1 & $16.9^{\mathrm{ab}}$ & $25.1^{\mathrm{b}}$ & $25.9^{\text {cde }}$ & $8.5^{\mathrm{bc}}$ & $12.4^{\mathrm{c}}$ \\
\hline 4. IR-74371-54-1-1 & 21.3 & $22.3^{b}$ & 14.2 & $12.5^{\mathrm{b}}$ & $25.1^{\mathrm{b}}$ & $25.5^{\mathrm{de}}$ & $10.6^{\mathrm{ab}}$ & $16.3^{\mathrm{ab}}$ \\
\hline 5. IR-78908-193-B-3-B & 21.0 & $30.5^{\mathrm{a}}$ & 14.5 & $22.5^{\mathrm{a}}$ & $25.4^{\mathrm{b}}$ & $26.7^{\mathrm{bc}}$ & $8.3^{\mathrm{bc}}$ & $16.5^{\mathrm{ab}}$ \\
\hline 6. IR-83614-281-B & 21.0 & $21.6^{\mathrm{b}}$ & 14.5 & $17.6^{\mathrm{ab}}$ & $25.1^{\mathrm{b}}$ & $26.5^{\mathrm{bcd}}$ & $7.5^{\mathrm{c}}$ & $13.3^{\mathrm{c}}$ \\
\hline 7. IR-83614-673-B & 24.2 & $24.8^{\mathrm{ab}}$ & 16.2 & $18.4^{\mathrm{ab}}$ & $26.1^{\mathrm{a}}$ & $27^{\mathrm{b}}$ & $7.2^{\mathrm{c}}$ & $15.6^{\mathrm{b}}$ \\
\hline 8. Radha-4 & 23.5 & $27.6^{\mathrm{ab}}$ & 16.1 & $21.9^{\mathrm{a}}$ & $26.4^{\mathrm{a}}$ & $28.6^{\mathrm{a}}$ & $7.4^{\mathrm{c}}$ & $13.1^{\mathrm{c}}$ \\
\hline S.Ed $( \pm)$ & 2.59 & 3.14 & 2.02 & 2.85 & 0.17 & 0.52 & 1037 & 1.01 \\
\hline LSD $(0.05)$ & 5.26 & 6.38 & 4.11 & 5.81 & 0.34 & 1.05 & 2.78 & 2.05 \\
\hline $\mathrm{CV}(\%)$ & 19.84 & 21.35 & 22.94 & 27.52 & 1.15 & 3.39 & 27.1 & 11.88 \\
\hline
\end{tabular}

$\%$ Values in a column with the same letter(s) are not significantly different at $P=0.05$ according to Duncan's Multiple Range Test. S.Ed: standard error of mean difference, LSD: least significant difference, $C V$ : coefficient of variation; 
The shattering percentage determines the threshability of the genotypes. The mean value ranged from 7 to $12 \%$ in 2009 , while it ranged from 12 to $18 \%$ during 2010 . According to IRRI (1996) this falls within the intermediate range of shattering (6-25\%) indicating that none of the tested genotypes had a serious problem with shattering before or during harvest (Table 4).

\section{Grain and straw yields}

Tested genotypes had significantly different grain yields in both years (Table 5). Across genotypes, the mean grain yield was 3.6 and 5.1 tons $^{-1} \mathrm{a}^{-1}$ in 2009 and 2010 , respectively. This mean difference of 1.6 tons ha ${ }^{-1}$ was due to a much higher drought stress in 2009 (68\% less rainfall than in 2010). Highest yielding lines in both years were IR-74371-54 and IR-74371-70, but only IR74371-54 had a significantly higher yield than the local control Radha-4. The good performance of these two lines was a combination of high yields in the drought-stressed season 2009 and a very high yield response to the good conditions in the 2010 season. High grain yields correlated with high numbers of filled grains panicle ${ }^{-1}$ (Table 3) in both seasons (e.g., see IR-74371-70 and IR-74371-54). In contrast, a high number of unfilled grains corresponded with low yields (e.g., see IR55419-04 and IR-78908-193).

Table 5. Grain yield, straw yield, biological yield and harvest index of the tested genotypes.

\begin{tabular}{|c|c|c|c|c|c|c|c|c|}
\hline \multirow{2}{*}{ Genotypes } & \multicolumn{2}{|c|}{$\begin{array}{l}\text { Grain yield } \\
\left(\mathrm{t} \mathrm{ha}^{-1}\right) \dagger\end{array}$} & \multicolumn{2}{|c|}{$\begin{array}{l}\text { Straw yield } \\
(\mathrm{t} \mathrm{ha-1}) \dagger\end{array}$} & \multicolumn{2}{|c|}{$\begin{array}{l}\text { Biological yield } \\
\left.\qquad(\mathrm{t} \mathrm{ha})^{-1}\right) \dagger\end{array}$} & \multicolumn{2}{|c|}{$\begin{array}{l}\text { Harvest Index } \\
\qquad(\%) \dagger\end{array}$} \\
\hline & 2009 & 2010 & 2009 & 2010 & 2009 & 2010 & 2009 & 2010 \\
\hline 1. IR-74371-70-1-1 & $3.93^{\mathrm{a}}$ & $5.62^{\mathrm{ab}}$ & $5.66^{\mathrm{b}}$ & $8.28^{\mathrm{ab}}$ & $9.6^{\mathrm{bc}}$ & $13.9^{\mathrm{ab}}$ & $40.7^{\mathrm{ab}}$ & $40.3^{\mathrm{c}}$ \\
\hline 2. IR-55419-04 & $3.10^{\mathrm{b}}$ & $4.80^{\mathrm{de}}$ & $5.97^{\mathrm{ab}}$ & $7.53^{\text {cde }}$ & $9.1^{\mathrm{bc}}$ & $12.5^{\mathrm{c}}$ & $34.2^{\mathrm{c}}$ & $38.8^{\mathrm{d}}$ \\
\hline 3. IR-74371-46-1-1 & $3.53^{\mathrm{ab}}$ & $5.52^{\mathrm{abc}}$ & $6.08^{\mathrm{ab}}$ & $7.85^{\mathrm{bcd}}$ & $9.6^{\mathrm{bc}}$ & $13.0^{\mathrm{abc}}$ & $36.4^{\mathrm{abc}}$ & $41.3^{\mathrm{b}}$ \\
\hline 4. IR-74371-54-1-1 & $3.96^{\mathrm{a}}$ & $5.97^{\mathrm{a}}$ & $5.96^{\mathrm{ab}}$ & $8.05^{\mathrm{bc}}$ & $9.9^{\mathrm{ab}}$ & $14.0^{\mathrm{a}}$ & $40.0^{\mathrm{ab}}$ & $42.6^{\mathrm{a}}$ \\
\hline 5. IR-78908-193-B-3-B & $3.56^{\mathrm{ab}}$ & $4.36^{\mathrm{ef}}$ & $5.63^{\mathrm{b}}$ & $8.72^{\mathrm{a}}$ & $9.2^{\mathrm{bc}}$ & $13.0^{\mathrm{abc}}$ & $39.4^{\mathrm{abc}}$ & $33.2^{\mathrm{f}}$ \\
\hline 6. IR-83614-281-B & $3.31^{\mathrm{b}}$ & $4.22^{\mathrm{f}}$ & $5.44^{\mathrm{b}}$ & $7.03^{\mathrm{e}}$ & $8.8^{c}$ & $11.2^{\mathrm{d}}$ & $37.9^{\mathrm{abc}}$ & $37.5^{\mathrm{e}}$ \\
\hline 7. IR-83614-673-B & $3.62^{\mathrm{ab}}$ & $5.14^{\mathrm{cd}}$ & $5.15^{\mathrm{b}}$ & $7.50^{\mathrm{de}}$ & $8.8^{c}$ & $12.83^{\mathrm{c}}$ & $41.3^{\mathrm{a}}$ & $40.5^{\text {bc }}$ \\
\hline 8. Radha-4 & $3.90^{\mathrm{a}}$ & $5.26^{\mathrm{bcd}}$ & $6.90^{\mathrm{a}}$ & $7.55^{\mathrm{cde}}$ & $10.8^{\mathrm{a}}$ & $13.0^{\mathrm{abc}}$ & $35.5^{\mathrm{bc}}$ & $40.8^{\mathrm{bc}}$ \\
\hline S.Ed $( \pm)$ & 0.28 & 0.22 & 0.51 & 0.26 & 0.55 & 0.45 & 2.80 & 0.28 \\
\hline $\operatorname{LSD}(0.05)$ & 0.58 & 0.46 & 1.02 & 0.53 & 1.1 & 0.92 & 5.71 & 5.7 \\
\hline CV (\%) & 13.65 & 7.73 & 15 & 5.75 & 10.0 & 6.09 & 4.04 & 7.18 \\
\hline
\end{tabular}

$\%$ Values in a column with the same letter(s) are not significantly different at $P=0.05$ according to Duncan's Multiple Range Test.S.Ed: standard error of mean difference, LSD: least significant difference, $C V$ : coefficient of variation;

The average straw yield across all germplams tested and all sites were 5.8 and 7.8 tons ha $^{-1}$ in 2009 and 2010, respectively. The straw yield of Radha-4 (farmer check) was highest during 2009, corresponding to the higher number of tillers hill ${ }^{-1}$ (Table 3). Surprisingly, the three tall lines tested (IR78908-193, IR-83614-281, IR83614-673) did not have particularly high straw yields except for IR78908-193 in the 2010 season.

Because of the drought stress in 2009, the average biological yield was considerably lower in $2009\left(9.5 \mathrm{t} \mathrm{ha}^{-1}\right)$ as compared with $2010\left(12.9 \mathrm{t} \mathrm{ha}^{-1}\right)$. The highest biological yield in 2009 was 
achieved by Radha-4 (10.8 tons ha $\left.{ }^{-1}\right)$ while in 2010 the highest value was observed for IR-74371-541-1 (14.0 tons $\left.\mathrm{ha}^{-1}\right)$. Unexpectedly, the drought stress in 2009 did not much affect the average harvest index (HI) which was $38.2 \%$ in 2009 and $39.4 \%$ in 2010 . Noteworthy is that the three tall test lines (IR78908-193, IR-83614-281, IR83614-673) slightly decreased their HI in the good season, whereas most other lines increased their HI in 2010.

\section{Root characters}

Root length and root weight of the tested genotypes were measured as indicators of their drought tolerance (Table 5). Slightly higher average root lengths were observed in 2009 whereas the root weight hill-1 was similar in both seasons. Higher root length is obviously a character that supports to absorb water from higher depth, helping to survive under drought stress conditions. In both seasons, maximum root length and root weight was found in IR-74371-54-1-1, confirming its overall superior performance. The maximum root weight bearing genotypes produced more grain yield which might be due to higher water and nutrient absorption capacity of the plants (Adhikari, 2009).

Table 6. Length and weight of roots of the tested genotypes.

\begin{tabular}{|l|c|c|c|c|c|c|}
\hline \multirow{2}{*}{ Genotypes } & \multicolumn{3}{|c|}{$\begin{array}{c}\text { Root length } \\
(\mathrm{cm}) \dagger^{\dagger}\end{array}$} & \multicolumn{3}{c|}{ Root weight hill $^{-1}$} \\
& 2009 & 2010 & Mean & 2009 & 2010 & Mean \\
\cline { 2 - 7 } 1. IR-74371-70-1-1 & $23.3^{\mathrm{bc}}$ & $22.7^{\mathrm{a}}$ & $23.0^{\mathrm{ab}}$ & $8.9^{\mathrm{bc}}$ & $8.7^{\mathrm{cd}}$ & $8.8^{\mathrm{cd}}$ \\
2. IR-55419-04 & $22.3^{\mathrm{bc}}$ & $20.9^{\mathrm{cd}}$ & $21.6^{\mathrm{bc}}$ & $9.0^{\mathrm{b}}$ & $8.6^{\mathrm{cd}}$ & $8.8^{\mathrm{cd}}$ \\
3. IR-74371-46-1-1 & $24.5^{\mathrm{ab}}$ & $22.5^{\mathrm{ab}}$ & $23.5^{\mathrm{a}}$ & $9.3^{\mathrm{ab}}$ & $9.5^{\mathrm{ab}}$ & $9.4^{\mathrm{ab}}$ \\
4. IR-74371-54-1-1 & $26.2^{\mathrm{a}}$ & $22.4^{\mathrm{abc}}$ & $24.3^{\mathrm{a}}$ & $9.8^{\mathrm{a}}$ & $10.0^{\mathrm{a}}$ & $9.9^{\mathrm{a}}$ \\
5. IR-78908-193-B-3-B & $22.2^{\mathrm{bc}}$ & $21.0^{\mathrm{bcd}}$ & $21.6^{\mathrm{bc}}$ & $8.4^{\mathrm{cd}}$ & $8.7^{\mathrm{cd}}$ & $8.5 \mathrm{~d}^{\mathrm{e}}$ \\
6. IR-83614-281-B & $21.8^{\mathrm{c}}$ & $20.2^{\mathrm{d}}$ & $21.0^{\mathrm{c}}$ & $8.2^{\mathrm{d}}$ & $8.3^{\mathrm{d}}$ & $8.2^{\mathrm{e}}$ \\
7. IR-83614-673-B & $23.8^{\mathrm{abc}}$ & $21.0^{\mathrm{bcd}}$ & $22.4^{\mathrm{abc}}$ & $8.4^{\mathrm{cd}}$ & $8.4^{\mathrm{d}}$ & $8.4^{\mathrm{de}}$ \\
8. Radha-4 & $23.8^{\mathrm{abc}}$ & $21.2^{\mathrm{bcd}}$ & $22.5^{\mathrm{abc}}$ & $9.0^{\mathrm{b}}$ & $9.2^{\mathrm{bc}}$ & $9.1^{\mathrm{bc}}$ \\
\hline S. Ed $( \pm)$ & 1.28 & 0.74 & 1.01 & 0.33 & 0.31 & 0.32 \\
\hline LSD (0.05) & 2.59 & 1.50 & 2.04 & 0.66 & 0.63 & 0.64 \\
\hline CV $(\%)$ & 9.41 & 5.95 & 7.68 & 6.38 & 6.04 & 6.21 \\
\hline
\end{tabular}

$\uparrow$ Values in a column with the same letter(s) are not significantly different at $P=0.05$ according to Duncan's Multiple Range Test. S.Ed: standard error of mean difference, LSD: least significant difference, $C V$ : coefficient of variation;

\section{Preference ranking of genotypes}

A total of 111 and 100 farmers were involved to select their preferred genotypes in the trials based on traits like earliness, plant height, length of panicles, size of grains, grain setting, tillering, lodging habit etc. at maturity stage of crop during 2009 and 2010 (entry names were not shown during the preference ranking). In 2009, the maximum preference score was secured by IR-7437154-1-1 (0.16) followed by IR-74371-46-1-1 (0.15) and IR-74371-70-1-1 (0.15), while the lowest score was given to IR-83614-281-B (-0.19). In 2010, the maximum preference score was secured by the same genotypes (IR-74371-54-1-1, 0.19; IR-74371-46-1-1, 0.11; IR-74371-70-1-1, 0.05) and the 
minimum score was given to IR-83614-281-B (-0.12). The first, second and third ranked genotypes were released in January 2011 by the variety releasing subcommittee of Nepal as Sukhadhan-2 (IR-74371-54-1-1), Sukhadhan-1 (IR-74371-46-1-1) and Sukhadhan-3(IR74371-70-1) as drought tolerant rice varieties for rainfed conditions in the Terai, inner Terai and the lower hilly areas of Nepal (Fig. 2). Kumar et al. (2012) also identified IR74371-70 and IR74371-46 as stable genotypes showing high yield under varied rainfed environments across many breeding trials conducted in India, Bangladesh and Nepal.

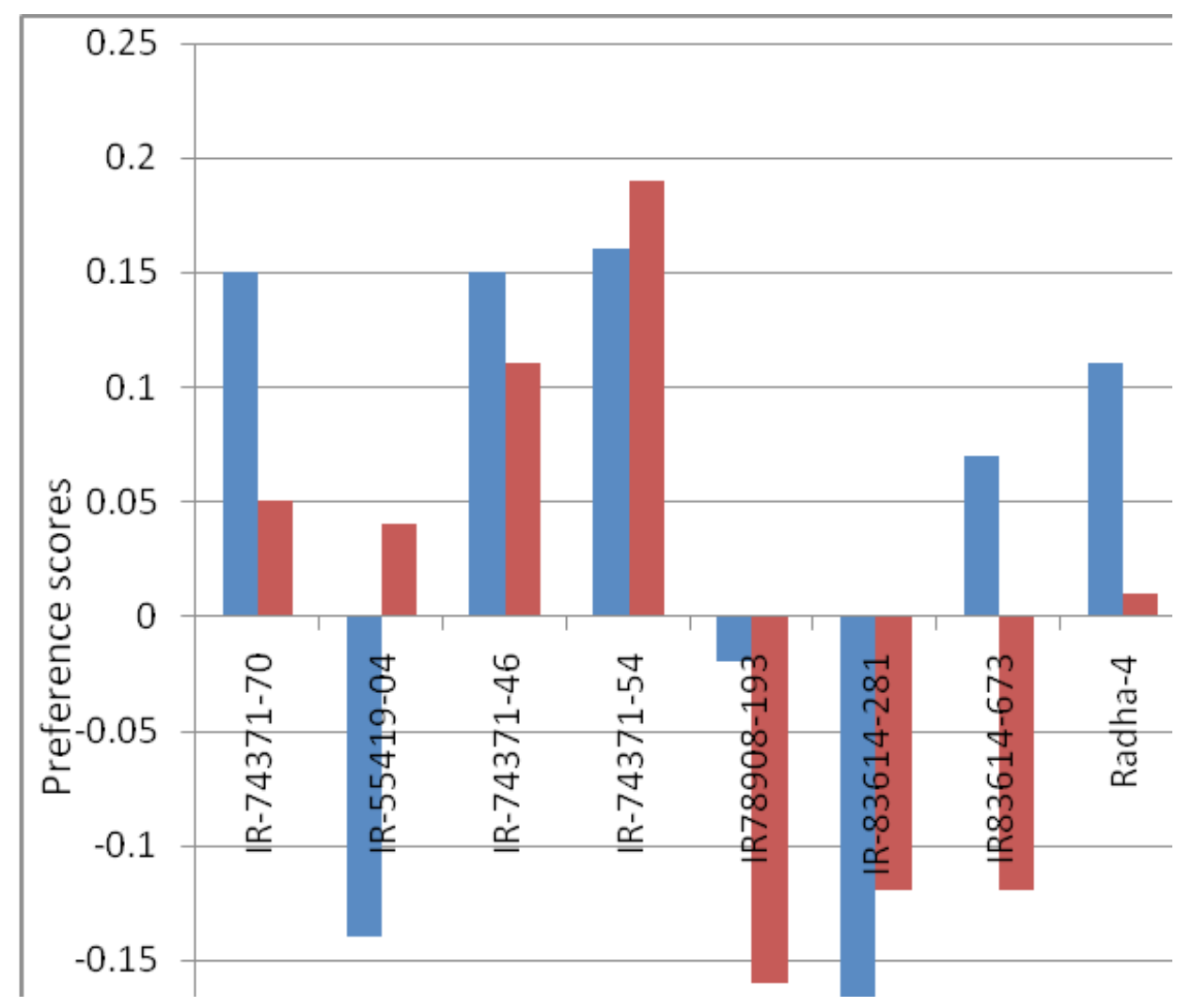

Fig. 2 Preference ranking scores of the tested genotypes

\section{Economic analysis}

The economic evaluation of the different genotypes used in the experiment as treatment was conducted to determine the most beneficial and economical genotype for rainfed conditions in the mid hills of Nepal. The average costs of cultivation were determined through short study surveys, conducted during 2009 and 2010 with 45 randomly selected farmers in Sundarbazar, Lamjung. The main objective was to determine the general cropping system and the related cost of cultivation of rainfed rice in the study area. The data showed that a total of Nepalese Rupees (NRs.) 75742 (equivalent to 891 US\$ at the 2010 exchange rate) was required to cultivate one hectare of rice in the study area (Table 7). The experimental cultivation practice from seeding to harvest was according to the general practice and there was no difference in inputs used between lines within the experiment. Therefore, there was no cost variation between different germplasm treatments. 
Table 7. General costs of rice production and product prices (Nepalese Rupees ha $\mathbf{~}^{-1}$ ) based on field surveys conducted during 2009 and 2010 at Sundarbazar,Lamjung (average values of two years)

\begin{tabular}{|c|c|c|c|c|c|}
\hline S.N. & Particular & Unit & Quantity & Rate (NR) & Total \\
\hline \multicolumn{6}{|c|}{ I . Variable cost } \\
\hline \multicolumn{6}{|c|}{ A. Nursery raising $\left(126 \mathrm{~m}^{2}\right)$ : } \\
\hline 1 & Land preparation by using bullocks & days & 1 & 280 & 280 \\
\hline 2 & Men labour & days & 2 & 250 & 500 \\
\hline 3 & Women labour & days & 2 & 170 & 340 \\
\hline 4 & Seed & $\mathrm{kg}$ & 65 & 73 & 4745 \\
\hline 5 & FYM & $\mathrm{kg}$ & 843 & 0.9 & 759 \\
\hline 6 & Urea for top dressing & $\mathrm{kg}$ & 3 & 25.0 & 75.0 \\
\hline \multicolumn{5}{|c|}{ Sub total } & 5.875 \\
\hline \multicolumn{6}{|c|}{ B. Land preparation and crop management (1 ha) } \\
\hline 1 & Bullock pair needs & days & 15 & 274 & 4110 \\
\hline 2 & Men labour & work days & 37 & 267 & 9916 \\
\hline 3 & Women labour & work days & 41 & 169 & 6929 \\
\hline 4 & FYM & $\mathrm{kg}$ & 3638 & 0.90 & 3274 \\
\hline 5 & DAP & $\mathrm{kg}$ & 40 & 38 & 1360 \\
\hline 6 & MOP & $\mathrm{kg}$ & 14 & 25 & 350 \\
\hline 7 & Urea (basal) & $\mathrm{kg}$ & 18 & 25 & 450 \\
\hline 8 & Urea (top dress) & $\mathrm{kg}$ & 70 & 25 & 1750 \\
\hline 9 & Men labour for weeding & work days & 40 & 170 & 6800 \\
\hline 10 & Women labour for weeding & work days & 34 & 170 & 5780 \\
\hline 11 & Men labour for harvesting & work days & 26 & 170 & 4420 \\
\hline 12 & Women for harvesting & work days & 25 & 170 & 4250 \\
\hline 13 & Men for CTCS* & work days & 43 & 265 & 11395 \\
\hline 14 & Women for CTCS* & work days & 19 & 240 & 4560 \\
\hline Sub & & & & & 65344 \\
\hline II. In & rest on variable cost for 6 months at & & & & 4273 \\
\hline III. F & xed cost: Govt. land tax for 6 months & $\mathrm{NRs} \mathrm{ha}^{-1}$ ye & & & 250 \\
\hline Tota & cost of production (from seed to se & & & & 75.742 \\
\hline Price & of coarse rice and straw at the farm & & Price & te $\left(\mathrm{NR} \mathrm{kg}^{-1}\right)$ & \\
\hline Pric & or coarse rice and straw al the rarn & & 2009 & 20 & \\
\hline Rice & rain, coarse rice & & 18 & 2 & \\
\hline Rice & rain, fine rice & & 20 & 2 & \\
\hline Rice & traw & & 5 & 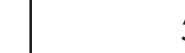 & \\
\hline
\end{tabular}

* CTCS $=$ Collection, threshing, cleaning and storage. 
During both years, the genotype IR-74371-54-1 produced the highest gross income (Rs.130452 per year) followed by IR-74371-70-1 (Rs.126478), Radha-4 (Rs. 123851) and IR-74371-461(Rs.121856). These calculations considered the value of straw, due to which Radha-4 has the highest gross income in 2009 although it has not the highest grain yield in that year. Since the net income was calculated by subtracting the same costs from all tested germplasm, the net income shows the same trends as the gross income. But the value of the net incomes shows how severe a drought year reduces farmers income from rice farming, because even the best performing variety Radha-4 results in an income of $29034 \mathrm{NR} \mathrm{ha}^{-1}$ only (equivalent to $324 \mathrm{US} \$$ at the 2010 exchange rate).

Table 8. Gross income, net income and benefit:cost ratio for all tested genotypes

\begin{tabular}{l|c|c|c|c|c|c}
\hline \multirow{2}{*}{ Genotypes } & \multicolumn{2}{|c|}{$\begin{array}{c}\text { Gross income } \\
(\text { Rs.ha-1 }\end{array}$} & \multicolumn{2}{c|}{$\begin{array}{c}\text { Net income } \\
\left(\text { Rs.ha }^{-1}\right)\end{array}$} & \multicolumn{2}{c}{ Benefit:cost ratio } \\
\cline { 2 - 7 } & 2009 & 2010 & 2009 & 2010 & 2009 & 2010 \\
\hline 1. IR-74371-70-1-1 & $99023^{\mathrm{ab}}$ & $153933^{\mathrm{a}}$ & $23281^{\mathrm{ab}}$ & $78191^{\mathrm{a}}$ & $1.307^{\mathrm{abc}}$ & $2.03^{\mathrm{a}}$ \\
2. IR-55419-04 & $85672^{\mathrm{c}}$ & $133658^{\mathrm{cd}}$ & $9929^{\mathrm{c}}$ & $57916^{\mathrm{cd}}$ & $1.131^{\mathrm{d}}$ & $1.76^{\mathrm{cd}}$ \\
3. IR-74371-46-1-1 & $94005^{\mathrm{abc}}$ & $149708^{\mathrm{ab}}$ & $18263^{\mathrm{abc}}$ & $73966^{\mathrm{ab}}$ & $1.341^{\mathrm{ab}}$ & $1.97^{\mathrm{ab}}$ \\
4. IR-74371-54-1-1 & $101063^{\mathrm{ab}}$ & $159842^{\mathrm{a}}$ & $25321^{\mathrm{ab}}$ & $84099^{\mathrm{a}}$ & $1.334^{\mathrm{ab}}$ & $2.11^{\mathrm{a}}$ \\
5. IR78908-193-B-3-B & $92350^{\mathrm{bc}}$ & $130800^{\mathrm{d}}$ & $16608^{\mathrm{bc}}$ & $55058^{\mathrm{d}}$ & $1.219^{\mathrm{bcd}}$ & $1.72^{\mathrm{d}}$ \\
6. IR-83614-281-B & $86917^{\mathrm{c}}$ & $119625^{\mathrm{e}}$ & $11174^{\mathrm{c}}$ & $43883^{\mathrm{e}}$ & $1.148^{\mathrm{d}}$ & $1.58^{\mathrm{e}}$ \\
7. IR83614-673-B & $90910^{\mathrm{bc}}$ & $140367 \mathrm{~b}^{\mathrm{cd}}$ & $15168^{\mathrm{bc}}$ & $64624^{\mathrm{bcd}}$ & $1.200^{\mathrm{cd}}$ & $1.85^{\mathrm{bcd}}$ \\
8. Radha-4 & $104776^{\mathrm{a}}$ & $142925^{\mathrm{bc}}$ & $29034^{\mathrm{a}}$ & $67183^{\mathrm{bc}}$ & $1.38^{\mathrm{a}}$ & $1.88^{\mathrm{bc}}$ \\
\hline S.Ed.( \pm$)$ & 5412.5 & 5408.0 & 5412.5 & 5408.0 & 0.07 & 0.07 \\
\hline LSD $(0.05)$ & 10990 & 10980 & 10990 & 10980 & 0.133 & 0.143 \\
\hline CV(\%) & 9.94 & 6.63 & 50.41 & 14.28 & 9.94 & 6.61 \\
\hline
\end{tabular}

$\digamma$ Values in a column with the same letter(s) are not significantly different at $P=0.05$ according to Duncan's Multiple Range Test. S.Ed: standard error of mean difference, LSD: least significant difference, $C V$ : coefficient of variation;

Benefit:cost ratio (B:C ratio) is the ratio of gross return and the cost of investment which can also be expressed as returns per rupee invested.The B:C ratios were rather low in 2009 (between 1.2 to 1.4 ) but reasonably high in 2010 (1.6 to 2.1). B:C values greater than 2 are considered a good return to investment for farmers (Reddy and Reddi, 2002). However, a minimum benefit:cost ratio $\geq 1.5$ has been considered as an economically viable agricultural enterprise (Bhandari, 1993). Based on the estimated B:C ratios we concluded that the use of IR-74371-54-1-1, IR-74371-70-1-1 and IR74371-46-1-1were economically viable and safe to cultivate for the farmers, and that they offer an advantage over the local check variety Radha-4.

\section{CONCLUSION}

Development of better rice varieties for the rainfed environment in Nepal has an important role for improving the livelihoods of farmers in these environments. However, varietal development for rainfed environments was often neglected and rarely successful. Our study shows the results of a successful testing and selection of new germplasm for the mid-hills of Nepal, combining participatory on-site research with a bio-physical and socio-economic evaluation of the new germplasm. The best 
lines tested, IR-74371-54-1, IR-74371-70-1 and IR-74371-46-1-1 were released in Nepal in 2011 as Sukhadhan-2, Sukhadhan-3 and Sukhadhan-1, respectively. These varieties can easily be fitted in the existing cropping system in rainfed lowlands, reduce the production risk in drought-prone environments and are economically viable for the farmers in the mid hills areas of Nepal.

\section{ACKNOWLEDGEMENT}

The authors thank and express sincere gratitude to the farmers for their active participation in the field research and field survey, which were important and crucial for successful accomplishment of this study. The study was supported by the Bill \& Melinda Gates Foundation (BMGF) through the project "Stress-Tolerant Rice for Poor Farmers in Africa and South Asia, Phase 1" and the International Rice Research Institute.

\section{REFERENCES CITED}

Adhikari, B. B. 2009. Preliminary evaluation of upland rice landraces for drought tolerance. J. Inst. Agric. Anim. Sci. 30: 73-78.

Bhandari, A. S. 1993. Sustainability measures of rice-wheat system across agro-ecological regions in Nepal. Ph. D. Dissertation (unpublished). Central, Luzon State University, Munz, Philippines.

Haefele, S. M,. B. K. Bhattachan, B. B. Adhikari, C. C. Abon Jr. and S. M. Shrestha. 2014. Spatial variability of fertilizer management and response in rainfed rice of Nepal. J. Agriculture, Ecosystems \& Environment 189: 190-198.

IRRI. 1996. Standard evaluation system for rice INGER Genetic Resource Centre ( $4^{\text {th }}$ ed). International Rice Research Institute, Manila, Philippines.

Joshy, D. and N. P. Rajbahandari. 2001. Agricultural development and food security in Nepal: Constraints and potential. In: H.K. Manandhar, C.L. Shrestha, R.K. Shrestha and S.M. Pradhan (Eds.) Advances in Agricultural Research in Nepal. Society of Agricultural Scientists (SAS) Nepal. pp. 24-29.

Karki, T. B., Y. R. Pandey,, K. B. Koirala, , S. B. BK, and K. H. Ghimire. 2007. On-farm Agricultural Research: An experience of Lumle. Proceedings of the $8^{\text {th }}$ National Outreach Research Workshop, 19-20 June, 2007. NARC, Nepal.

Kumar, A., S. B. Verulkar, N. P. Mandal, M. Variar, V. D. Shukla, J. L. Dwivedi, B.N. Singh, O.N. Singh, P. Swain, A. K. Mall, S. Robin, R. Chandrababu, A. S. M. Jain, Haefele, H. P. Piephoi, A. Raman. 2012. High-yielding, drought-tolerant, stable rice genotypes for the shallow rainfed lowland drought-prone ecosystem. Field Crops Res., 133:37-47.

MOAC. 2009. Statistical information on Nepalese agriculture (2008/09). Agribusiness Promotion and Statistics Division, Singha Darabar, Kathmandu, Nepal.

MOAD. 2012/013. Statistical Information on Nepalese Agriculture. Ministry of Agriculture and C0operatives, Agri-business Promotion and Statistical Division, Singha Durbar, Kathmandu, Nepal.

Pandey, S., H. Bhandari, and B. Hardy. 2007. Economic costs of drought and rice farmers' coping mechanisms: A cross country comparative analysis. International Rice Research Institute (IRRI), Los Banas, Philippins.

Reddy, T. Y. and G. H. S. Reddi. 2002. Principles of agronomy (3 ${ }^{\text {rd }}$ ed.). Kalyani Publishers, New Delhi, India, 526 p.

Sherchan, D.P. and K.B. Karki. 2006. Plant nutrient management of improving crop productivity in Nepal. pp 15-22. In: Improving plant nutrient management for better farmer livelihoods, food security and environmental sustainability; Proceedings of a regional workshop, Beijing, China, (December 12-16, 2005). RAP Publication (FAO), no. 2006/27 / FAO, Bangkok (Thailand). Regional Office for Asia and the Pacific 2006. 